Buana Sains Vol 18 No 2: 139 - 148, 2018

\title{
PENGARUH LAMA PENGOMPOSAN SERBUK GERGAJI KAYU JATI DAN DOSIS EM4 TERHADAP PERTUMBUHAN DAN HASIL TANAMAN KUBIS BUNGA (Brassica oleracea L.) DATARAN RENDAH
}

\author{
Sri Hariningsih Pratiwi dan Retno Tri Purnamasari
}

Fakultas Pertanian, Universitas Merdeka Pasuruan

\begin{abstract}
This research was purposed to find out whether there was any significant correlation of the composting time of teak sawdust and EM4 dose on the growth and yield of lowland flower cabbage plants or not. This research was carried out at the Experimental Field of Universitas Merdeka Pasuruan (Sultan Agung Street), Pasuruan City at an altitude of $4 \mathrm{~m}$-asl.

This research used factorial Randomized Block Design (RBD) method consisted of two factors and repeated three times. The first factor was the length of composting (L) with $\mathrm{L}_{1}$ : one month, $\mathrm{L}_{2}$ : two months and $\mathrm{L}_{3}$ : three months. The second factor was the dose of EM4 (D) with $\mathrm{D}_{1}: 10 \%$ EM4 dose, $\mathrm{D}_{2}: 20 \%$ EM4 dose and $\mathrm{D}_{3}: 30 \%$ EM4 dose. Overall there were nine combinations of treatments.

The results showed that there was $20 \%$ EM4 dose with a 2 months composting time yielded higher results on all observed parameters. Flower cabbage with a dose of $20 \%$ EM4 with composting time of 2 months produced fresh weight of 15.97 tons ha ${ }^{-1}$, at a dose of EM4 $20 \%$ with a composting time of 1 month produced fresh weight 13.86 tons $\mathrm{ha}^{-1}$, while the lowest yield at dose of $20 \%$ EM4 with a composting time of 3 months produced fresh weight 9.79 tons ha ${ }^{-1}$.
\end{abstract}

Keywords: Composting; sawdust; EM4; production; flower cabbage.

\section{Pendahuluan}

Saat ini beberapa petani di Kabupaten Pasuruan mengusahakan penanaman kubis bunga yaitu sejak ditemukannya varitas kubis bunga dataran rendah, hal ini didukung dengan tingginya permintaaan. Kebutuhan kubis bunga selama ini dipenuhi dari wilayah dataran tinggi. Penanaman kubis bunga di dataran rendah umumnya dilakukan pada lahan sawah yang kandungan $\mathrm{C}$ organik dan $\mathrm{C} / \mathrm{N}$ ratio rendah $(1,48$ dan 10,41). Untuk mendukung pertumbuhan dan hasil yang tinggi, tanaman kubis bunga membutuhkan tanah yang kesuburan fisik, kimia dan biologis yang tinggi, hal tersebut dapat dipenuhi dengan penambahan bahan organik. Salah satu bahan organik yang dapat digunakan adalah kompos serbuk gergaji yang berasal dari limbah dari industri mebel.

Limbah serbuk gergaji di Kabupaten Pasuruan cukup melimpah, dikarenakan semakin berkembangnya kerajinan kayu baik untuk bahan-bahan kerajinan dan yang paling menonjol adalah usaha mebel, sebanyak 96\% merupakan industri kecil dengan 
kapasitas produksi sebesar 19.991 buah (BPS, 2016). Adanya limbah tersebut akan menimbulkan dampak negatif terhadap lingkungan, untuk itu diperlukan penanganan antara lain dengan memanfaatkannya menjadi kompos. Serbuk gergaji ada yang berasal dari bahan kayu lunak dan keras yang mana kekerasan jenis kayu menentukan lama proses pengomposan, dikarenakan kandungan lignin yang tinggi di dalam kayu tersebut.

Di Kabupaten Pasuruan umumnya pembuatan mebel jenis kayu yang digunakan adalah kayu jati, yang termasuk jenis kayu keras dan apabila dikomposkan secara alami akan membutuhkan waktu yang sangat lama. Hardiwinoto, et al. (1996) menyebutkan bahwa bahan organik kayu mempunyai kandungan nutrisi rendah dan nisbah $\mathrm{C} / \mathrm{N}$ tinggi sehingga tidak dapat langsung digunakan. Untuk mempercepat proses pengomposan secara fisik dilakukan dengan memperkecil ukuran bahan, sedangkan secara kimia dapat dilakukan dengan memberikan dekomposer atau bioaktivator seperti EM4 ataupun mikrorganisme lainnya. Pusat Pendidikan Lingkungan Hidup (2007) menyatakan bahwa, pembuatan kompos serbuk gergaji kayu tusam (Pinus merkusii) dan serbuk gergaji kayu karet (Hevea braziliensis) dengan menggunakan aktivator EM4 dan pupuk kandang menghasilkan kompos dengan nisbah C/N 19,94 dan rendemen 85\% dalam waktu 4 bulan.

Effective Microorganism 4 (EM4) merupakan salah satu bioaktivator yang dapat dapat digunakan untuk mempercepat pengomposan. Hasil dari penelitian Siswati, Herwindo dan Puguh, (2009) menunjukkan bahwa penggunaan EM4 dengan konsentrasi $2 \%$ pada limbah industri kertas dapat menurunkan C/N dari 33,24 menjadi 14,11 dalam waktu 25 hari menunjukkan hasil terbaik. Sedangkan hasil penelitian Manuputty, Jacob dan Haumahu (2012) melaporkan EM4 dosis $300 \mathrm{ml} / 10 \mathrm{~kg}$ dari sampah di Kota Ambon paling efektif dalam mempercepat laju dekomposisi dan meningkatkan kualitas kimia kompos dari sampah di kota Ambon dibandingkan bioaktivator Promi.

\section{Metode Penelitian}

Penelitian dilaksanakan di Lahan Percobaan Universitas Merdeka Pasuruan (Jl. Sultan Agung), Kota Pasuruan pada ketinggian $4 \mathrm{~m} \mathrm{dpl}$.

Penelitian menggunakan metode Rancangan Acak Kelompok (RAK) faktorial yang terdiri dari dua faktor dan diulang tiga kali. Faktor pertama adalah lama pengomposan $(\mathrm{L})$ dengan taraf $\mathrm{L}_{1}$ : satu bulan, $\mathrm{L}_{2}$ : dua bulan dan $\mathrm{L}_{3}$ : tiga bulan. Faktor kedua adalah Dosis EM4 (D) dengan taraf $\mathrm{D}_{1}:$ Dosis EM4 $10 \%$, $\mathrm{D}_{2}$ : Dosis EM4 $20 \%$ dan $\mathrm{D}_{3}$ : Dosis EM4 $30 \%$. Secara keseluruhan terdapat sembilan kombinasi perlakuan.

Pengamatan yang dilakukan setelah pengomposan serbuk gergaji meliputi penilaian tingkat kematangan kompos yang dilihat dari karakteristik fisik kompos yang meliputi temperatur, bau dan warna serta $\mathrm{C} / \mathrm{N}$ rasio. Pengamatan terhadap tanaman kubis bunga terdiri atas pengamatan komponen pertumbuhan dan komponen hasil. Pengamatan pada beberapa komponen pertumbuhan meliputi: tinggi tanaman, jumlah daun, luas daun dan bobot kering total tanaman. Komponen hasil meliputi: diameter bunga, bobot segar bunga tanaman ${ }^{-1}$ dan bobot segar bunga hektar ${ }^{-1}$. 


\section{Hasil dan Pembahasan}

\section{Tinggi Tanaman}

Tinggi tanaman dengan nilai tertinggi terdapat pada perlakuan dosis EM4 20\% dan lama pengomposan 2 bulan, hal ini dapat disebabkan oleh unsur hara yang terdapat pada kompos tersebut dapat digunakan oleh tanaman. Menurut Purwanti (2007), bahan organik yang terdekomposisi sempurna memiliki ketersediaan unsur hara lebih cepat diserap oleh akar tanaman.

Kematangan kompos juga berpengaruh terhadap unsur hara yang dihasilkan. Sesuai dengan prinsip pengomposan yang menurunkan nilai rasio $\mathrm{C} / \mathrm{N}$ bahan organik menjadi sama atau mendekati dengan rasio $\mathrm{C} / \mathrm{N}$ tanah. Nilai $\mathrm{C} / \mathrm{N}$ ratio pada serbuk gergaji sebelum dilakukan pengomposan sebesar 143 sedangkan setelah dikomposkan mengalami penurunan pada setiap perlakuan seperti pada Gambar 1.

Perlakuan dosis EM4 20\% dengan lama pengomposan 2 bulan $\left(\mathrm{D}_{2} \mathrm{~L}_{2}\right)$ menunjukkan nilai $\mathrm{C} / \mathrm{N}$ ratio terendah sehingga akan mendukung hasil tinggi tanaman lebih tinggi dibandingkan dengan perlakuan lainnya, sedangkan nisbah $\mathrm{C} / \mathrm{N}$ yang tinggi memiliki kandungan nutrisi yang rendah, menandakan laju dekomposisi yang lambat dan kurang mendukung jika langsung digunakan sebagai bahan baku media tanam. Rendahnya $\mathrm{C} / \mathrm{N}$ yang dihasilkan dikarenakan unsur karbon organik yang ada pada serbuk gergaji telah terdekomposisi dengan bantuan bakteri yang terdapat pada EM4. Sejalan dengan hasil penelitian Nurjanto, et al. (2005) yang menyebutkan bahwa pemberian bahan organik ber nisba $\mathrm{C} / \mathrm{N}$ rendah tanpa pemberian EM4 pada limbah kulit kayu yang ber nisbah $\mathrm{C} / \mathrm{N}$ tinggi tidak menunjukkan penurunan hasil $\mathrm{C} / \mathrm{N}$, sedangkan dengan penambahan bahan organik dan EM4 pada limbah kulit kayu memberikan pengaruh nyata pada penurunan nisbah C/N yakni 41,66 pada $K_{1}$ dan 33,85 pada $\mathrm{K}_{2}$.

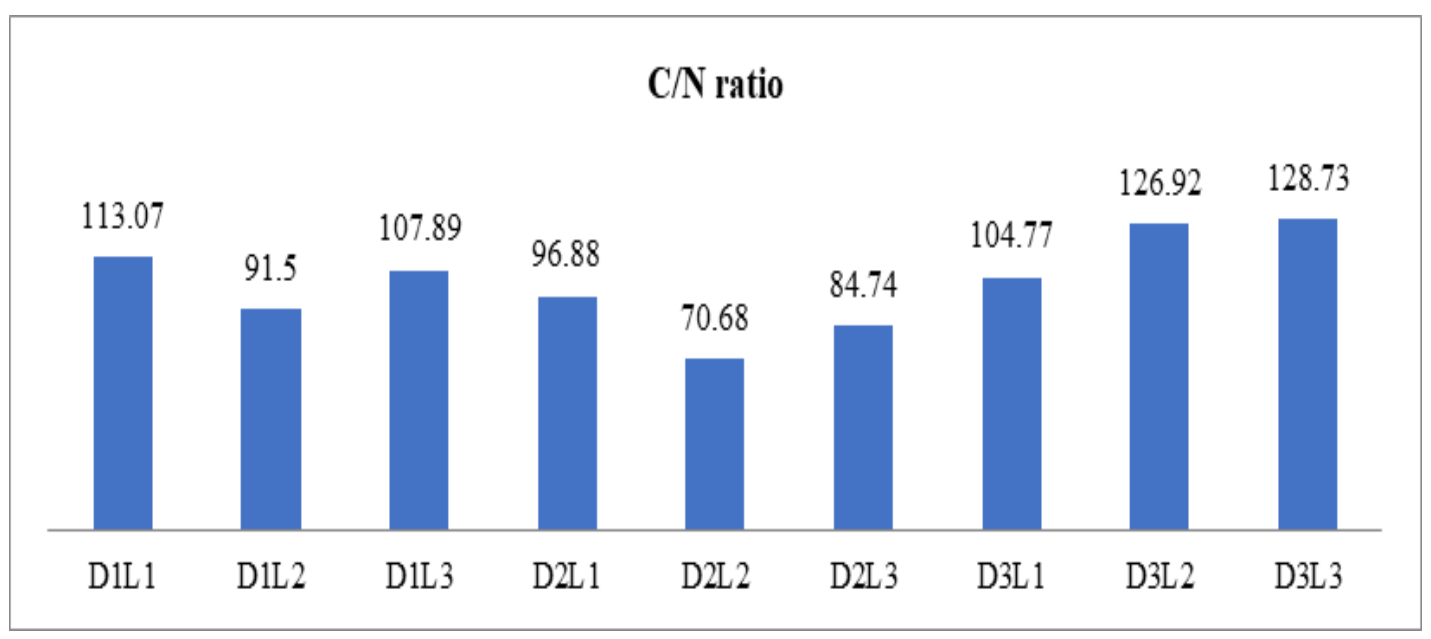

Gambar 1. Nisbah C/N ratio dalam kompos pada tiap perlakuan

Tabel 1. Pengaruh interaksi perlakuan dosis EM4 dan lama pengomposan terhadap 
S. H. Pratiwi dan R. T. Purnamasari/ Buana Sains Vol 18 No 2 : 139-148

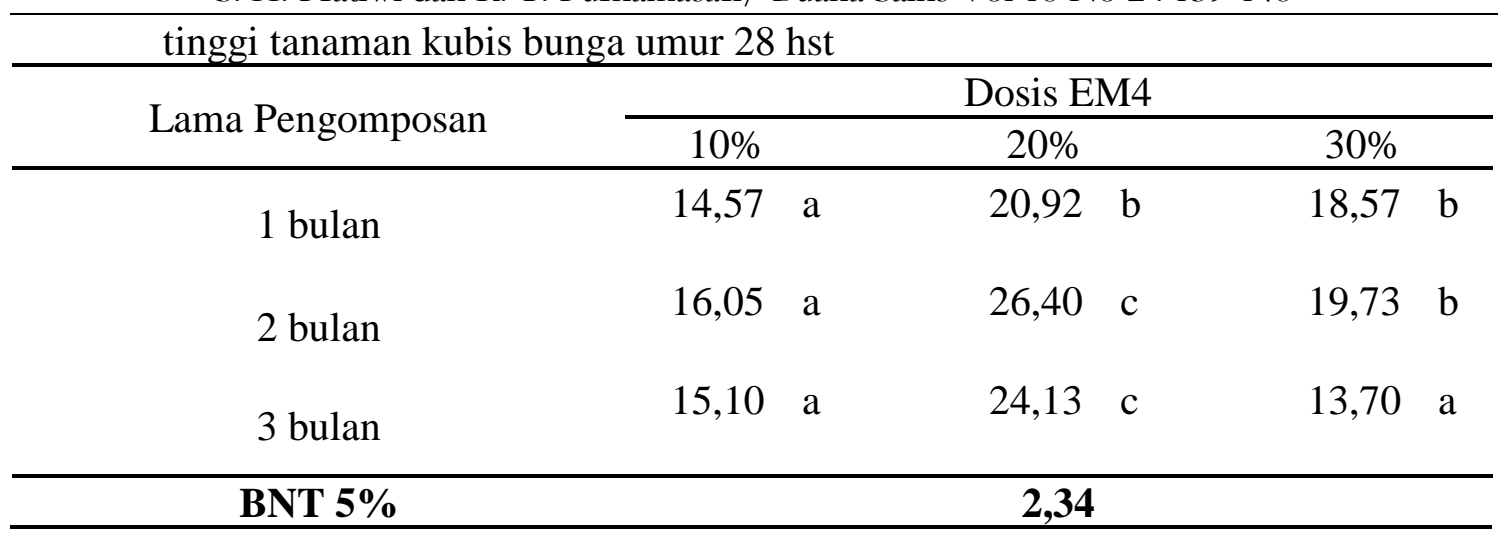

Keterangan: Angka-angka yang didampingi huruf besar yang sama pada kolom yang sama dan huruf kecil yang sama pada baris yang sama menunjukkan tidak berbeda nyata pada uji BNT 5\%.

Pemberian dari bentuk effective mikroorganisme berfungsi sebagai dekomposer dari bahan organik menjadi kompos. Semakin banyak EM4 yang diberikan pada serbuk gergaji, maka semakin banyak mikroorganisme yang dapat merombak senyawa makro menjadi mikro yang tersedia bagi tanaman. Sejalan dengan penelitian Mirwan dan Firra (2016) yang menunjukkan bahwa sampel yang penambahan konsentrasi efektif mikrorganisme paling banyak (100 $\mathrm{ml}$ ), memiliki kandungan nutrisi yang paling banyak pula. Tetapi pada percobaan pengaruh dosis EM4 dengan lama pengomposan pemberian dosis tertinggi tidak menunjukkan penurunan nisbah $\mathrm{C} / \mathrm{N}$ ratio yang banyak dan tidak berpengaruh pada bertambah tingginya tinggi tanaman. Hal ini dikarenakan jumlah makanan pada serbuk gergaji tidak sebanding dengan jumlah mikroba, sehingga terjadi persaingan antar mikroba untuk mendapatkan makanan dan berakibat negatif pada perubahan rasio C/N. Sejalan dengan penelitian Dyah, et al. (2009) yang menyatakan bahwa pemberian EM4 sebanyak 10\% pada waktu dekomposisi 20 hari menunjukkan penurunan $\mathrm{C} / \mathrm{N}$ ratio menjadi 17,5 sedangkan pada pemberian EM4 2\% menghasilkan penurunan $\mathrm{C} / \mathrm{N}$ ratio menjadi 15,0.

Lama waktu pengomposan juga berpengaruh tinggi tanaman, hasil $\mathrm{C} / \mathrm{N}$ terbaik terdapat pada lama pengomposan 2 bulan. Lama waktu pengomposan yang digunakan juga harus sebanding dengan jumlah EM4 yang diberikan dan memperhatikan fase dimana keadaan mikroba tersebut masih dikatakan aktif atau masih dalam fase stationary. Hal ini sejalan dengan penelitian yang telah dilakukan Farid (2011) yang menyatakan bahwa pengomposan media yang terlalu lama dapat berakibat nutrisi yang terkandung banyak hilang karena proses dekomposisi, mengingat mikrorganisme jamur merupakan salah satu tanaman pengurai yang dapat merombak nutrisi pada media tumbuh.

\section{Jumlah Daun}

Hasil analisis dari kandungan nitrogen pada akhir pengomposan (Gambar 2.) menunjukkan bahwa dosis EM4 $20 \%$ dengan lama pengomposan 2 bulan $\left(\mathrm{D}_{2} \mathrm{~L}_{2}\right)$ memiliki kandungan hara $\mathrm{N}$ yang tinggi sehingga berpengaruh pada bertambahnya jumlah daun pada tanaman kubis bunga. 
S. H. Pratiwi dan R. T. Purnamasari/ Buana Sains Vol 18 No 2 : 139-148

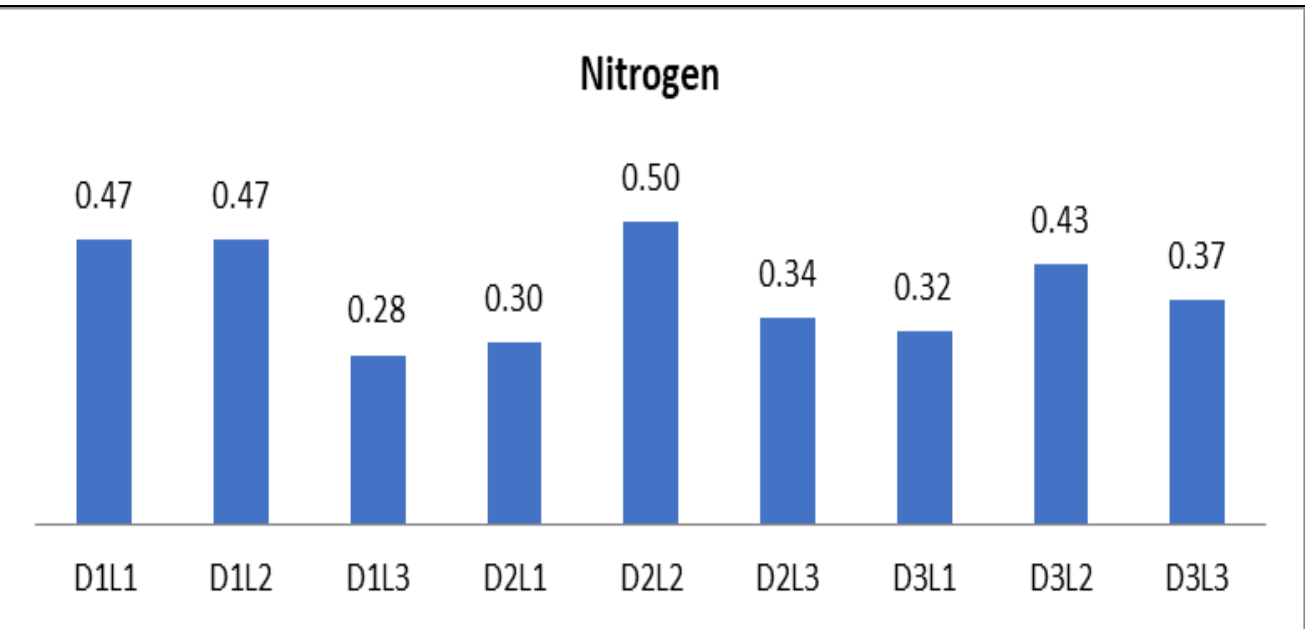

Gambar 2. Unsur hara nitrogen pada akhir pengomposan

Sutedjo (2010) menyatakan bahwa nitrogen merupakan unsur hara yang penting untuk meningkatkan pertumbuhan tanaman, meningkatkan pertumbuhan daun, daun tanaman lebar dengan warna yang lebih hijau dan pada umumnya sangat diperlukan untuk pembentukan atau pertumbuhan bagianbagian vegetatif tanaman seperti daun, batang dan akar. Hal ini menunjukkan dengan konsentrasi EM4 20\% dan lama pengomposan 2 bulan mikroba pada EM4 sudah mampu mendekomposisi serbuk gergaji dan dapat menunjang bertambahnya jumlah daun pada tanaman kubis bunga.
Pada proses pengomposan, nitrogen berfungsi sebagai makanan dari bakteri dekomposer, setelah itu pada fase terakhir pertumbuhan bakteri akan meningkatkan suhu kompos yang menandakan proses dekomposer berjalan optimal. Ketersediaan asupan nutrisi yang cukup akan mempengaruhi kerja dari bakteri. Bertambahnya jumlah daun menunjukkan keefektifan kerja dari dosis EM4 yang diberikan sehingga proses dekomposer berjalan optimal dan tanaman dapat memanfaatkan nitrogen untuk membentukan organ vegetatif.

Tabel 2. Pengaruh interaksi perlakuan dosis EM4 dan lama pengomposan terhadap jumlah daun tanaman kubis bunga umur $28 \mathrm{hst}$

\begin{tabular}{|c|c|c|c|c|c|c|}
\hline \multirow{2}{*}{ Lama Pengomposan } & \multicolumn{6}{|c|}{ Dosis EM4 } \\
\hline & $10 \%$ & & $20 \%$ & & $30 \%$ & \\
\hline 1 bulan & 7,33 & a & 9,40 & $\mathrm{~b}$ & 8,13 & $\mathrm{a}$ \\
\hline 2 bulan & 7,93 & a & 10,33 & $\mathrm{~b}$ & 7,80 & $\mathrm{a}$ \\
\hline 3 bulan & 8,53 & $\mathrm{a}$ & 9,67 & $\mathrm{~b}$ & 9,00 & $\mathrm{a}$ \\
\hline
\end{tabular}

Keterangan: Angka-angka yang didampingi huruf besar yang sama pada kolom yang sama dan huruf kecil yang sama pada baris yang sama menunjukkan tidak berbeda nyata pada uji BNT 5\%. 
Lama pengomposan juga berpengaruh pada jumlah daun tanaman kubis bunga, hal ini berhubungan dengan waktu mikroba dalam melakukan dekomposisi. Lama waktu pengomposan 2 bulan dengan dosis EM4 20\% menghasilkan hara nitrogen pada serbuk gergaji meningkat. Fase penguraian dapat dikatakan baik jika terdapat kenaikan pada hasil nitrogen. Sejalan dengan penelitian Mirwan dan Firra (2016) yang menyatakan bahwa terdapat pengaruh lamanya waktu pengomposan terhadap nilai $\mathrm{N}$ total pada fase hari ke 15 , selanjutnya mikroorganisme mencapai keseimbangan dimana jumlah mikroorganisme yang tumbuh sama dengan jumlah mikroorganisme yang mati yang disebabkan kurangnya makanan dan nutrisi.

\section{Luas Daun}

Semakin banyak jumlah daun, maka luas daun yang dihasilkan semakin tinggi. Hasil luas daun meningkat dikarenakan jumlah dan ukuran daun yang meningkat karena adanya interaksi antara dosis EM4 dengan lama pengomposan. Luas daun tanaman kubis bunga tertinggi terdapat pada perlakuan dosis EM4 20\% dengan lama pengomposan 2 bulan $\left(\mathrm{D}_{2} \mathrm{~L}_{2}\right)$. EM4 mengandung banyak mikroorganisme, terutama asam laktat, bakteri serta ragi untuk mempercepat penguraian bahan organik. Hasil dari proses ini akan meningkatkan ketersediaan unsur hara sehingga mudah diserap tanaman.

Proses perombakan berhubungan dengan rasio $\mathrm{C} / \mathrm{N}$ dimana semakin banyak kandungan karbon organik pada serbuk geraji akan mengakibatkan semakin lama kompos tersebut terdekomposisi. Selain itu kurangnya suplai nitrogen pada proses pengomposan akan menghambat serbuk gergaji terdekomposisi. Pada perlakuan lama pengomposan 2 bulan sudah dapat mendukung aktifitas mikroba pada EM4 untuk melakukan dekomposisi secara optimal sehingga dapat diserap oleh tanaman dan berimbas pada bertambahnya luas daun. Hal ini didukung dengan pernyataan Banie (2007) yang mengatakan bahwa posfor dan kalium penting dalam proses fermentasi dan akan dimanfaatkan oleh mikroba selama fermentasi, lamamya pengomposan dan konsentrasi aktifator akan berpengaruh pada unsur hara yang dihasilkan.

Tabel 3. Pengaruh interaksi perlakuan dosis EM4 dan lama pengomposan terhadap luas daun tanaman kubis bunga umur 28 hst

\begin{tabular}{|c|c|c|c|c|c|c|}
\hline \multirow{2}{*}{ Lama Pengomposan } & \multicolumn{6}{|c|}{ Dosis EM4 } \\
\hline & $10 \%$ & & $20 \%$ & & $30 \%$ & \\
\hline 1 bulan & 206,95 & $\mathrm{a}$ & 308,79 & $\mathrm{~b}$ & 241,36 & $\mathrm{ab}$ \\
\hline 2 bulan & 244,04 & $\mathrm{ab}$ & 359,67 & $\mathrm{~b}$ & 218,21 & a \\
\hline 3 bulan & 122,22 & $\mathrm{a}$ & 273,52 & $\mathrm{~b}$ & 209,79 & $\mathrm{~b}$ \\
\hline BNT 5\% & & & 70,09 & & & \\
\hline
\end{tabular}

Keterangan: Angka-angka yang didampingi huruf besar yang sama pada kolom yang sama dan huruf kecil yang sama pada baris yang sama menunjukkan tidak berbeda nyata pada uji BNT 5\%. 


\section{Bobot Kering Total Tanaman}

Hasil bobot kering total tanaman tertinggi pada Tabel 4. terdapat pada perlakuan dosis EM4 20\%. Hal ini didukung dengan hasil luas daun yang tinggi, semakin luas daun yang dimiliki suatu tanaman maka proses fotosintesis akan maksimal dan menghasilkan fotosintat yang tinggi untuk membentuk organ vegetatif baru, bertambahnya organ baru pada tanaman akan berpengaruh pada bertambahnya nilai dari bobot kering tanaman. Menurut Gardner, et al. (1991) menyatakan bahwa faktor utama yang mempengaruhi bobot kering tanaman adalah radiasi matahari yang diabsorpsi dan efisiensi, pemanfaatan energi tersebut untuk fiksasi karbondioksida $\left(\mathrm{CO}_{2}\right)$.

Peningkatan bobot kering juga dipengaruhi oleh pemberian dosis EM4 $20 \%$ pada saat pembuatan kompos. Menurut Moloney (1986) bobot kering akan bertambah dengan semakin bertambahnya kandungan nitrogen dan fospor dalam tanah. Sejalan dengan penelitian Jumiati (2009) yang menunjukkan hasil bobot kering total tertinggi terdapat pada perlakuan pemberian EM4 pada pupuk kandang ayam sebesar $1,15 \mathrm{~g}$ dibandingkan dengan tanpa pemberian EM4 yang menunjukkan nilai bobot kering total tanaman sebesar $0,26 \mathrm{~g}$.

\section{Diameter Bunga}

Perlakuan dosis EM4 dengan kombinasi lama pengomposan menunjukkan pengaruh nyata pada diameter tanaman kubis bunga, hasil tertinggi terdapat pada perlakuan dosis EM4 20\% dengan lama pengomposan 2 bulan seperti terlihat pada table 5 . Hal ini dikarenakan unsur hara fosfor yang berfungsi menunjuang fase generatif tersedia oleh tanaman. Menurut Rasyid (2013), unsur hara P berfungsi untuk merangsang pertumbuhan akar, membantu asimilasi dan pernafasan sekaligus mempercepat pembungaan, pemasakan buah dan biji. Hasil penelitian Sari (2005) menunjukkan bahwa pengomposan secara nyata meningkatkan unsur $\mathrm{P}$ dan $\mathrm{K}$. Pengomposan menunjukkan unsur $\mathrm{K}$ sebesar 13,85 ppm pada awal dan menjadi 25-31 ppm pada akhir pengomposan, peningkatan unsur P pada awal sebesar $125 \mathrm{ppm}$ dan menjadi 137,41 ppm pada akhir pengomposan

Tabel 4. Pengaruh perlakuan dosis EM4 dan lama pengomposan terhadap bobot kering total tanaman kubis bunga pada umur 28 hst

\begin{tabular}{cc}
\hline Perlakuan & Bobot Kering Total Tanaman \\
\hline Lama Pengomposan & 3,76 \\
1 bulan & 3,93 \\
2 bulan & 3,82 \\
\hline bulan & tn \\
\hline BNT 5 \% & \\
\hline Dosis EM4 & $3,24 \quad$ a \\
10\% & 4,79 b \\
20\% & $3,48 \quad$ a \\
\hline 30\% & $\mathbf{0 , 1 8}$ \\
\hline BNT 5 \%
\end{tabular}

Keterangan: Angka-angka yang didampingi huruf yang sama pada kolom yang sama menunjukkan tidak berbeda nyata pada uji BNT 5\%. 
EM4 dengan dosis 20\% dengan kombinasi lama pengomposan 2 bulan mampu menunjang bakteri dan jamur melakukan dekomposisi hingga menghasilkan nutrisi yang dapat digunakan oleh tanaman, hal ini berkaitan dengan sifat kimia kompos. diameter kubis bunga yang lebih tinggi seiring dengan perkembangan jumlah dan luas daun serta bobot kering tanaman yang dihasilkan, semakin besar jumlah dan luas daun maka bobot kering total tanaman meningkat dan diikuti dengan meningkatnya diameter bunga tanaman. Sejalan dengan penelitian soepardi (2013) yang mengatakan bahwa hara nitrogen mampu merangsang pertumbuhan tanaman diatas tanah dan salah satunya adalah meningkatnya diameter tanaman.

Lama pengomposan 2 bulan EM4 dengan dosis 20\% berpengaruh pada peningkatan ketersedian unsur hara pada kompos. Menurut Sari (2005), kecepatan dekomposisi kompos teh padat berhubungan dengan lama pengomposan dan berpengaruh pada peningkatan ketersediaan unsur hara baik makro maupun mikro. Didukung dengan hasil penelitiannya yang menyebutkan bahwa kandungan $\mathrm{N} 0,11 \%$ dan dengan adanya pengomposan terjadi peningkatan unusr $\mathrm{N}$ total menjadi 0,26 pada 5 hari pengomposan, $0,29 \%$ pada 10 hari pengomposan, $0,30 \%$ pada 15 hari pengomposan dan $0,33 \%$ pada 20 hari pengomposan. Meskipun hanya dengan interval waktu pengamatan 5 hari tetapi terjadi peningkatan $\mathrm{N}$ yang cukup berarti selama pengomposan dan diduga karena pemberian EM4 yang berpotensi mempercepat peningkatan $\mathrm{N}$ total.

\section{Bobot Segar Bunga Tanaman}

Bobot segar bunga tanaman pada Tabel 6. menunjukkan hasil tertinggi pada perlakuan dosis EM4 20\% dengan lama pengomposan 2 bulan. Ketersediaan unsur hara pada pengomposan perlakuan tersebut menyebabkan pertumbuhan serta menunjang hasil panen yang optimum. Hasil bobot segar tanaman ${ }^{-1}$ berbanding lurus dengan hasil diameter bunga, sehingga semakin besar diameter bunga yang dihasilkan maka bobot segar tanaman $^{-1}$ semakin tinggi dan berpotensi meningkatkan hasil panen semakin besar. kecukupan unsur hara yang dihasilkan dari interaksi dosis EM4 20\% dengan lama pengomposan 2 bulan pada proses dekomposisi menghasilkan pertumbuhan yang optimal pada tanaman.

Tabel 6. Pengaruh interaksi perlakuan dosis EM4 dan lama pengomposan terhadap bobot segar bunga tanaman ${ }^{-1}(\mathrm{~g})$ kubis bunga

\begin{tabular}{crrrrrr}
\hline \multirow{2}{*}{ Lama Pengomposan } & \multicolumn{5}{c}{ Dosis EM4 } \\
\cline { 2 - 6 } & 281,33 & a & 347,00 & b & 266,00 & a \\
\hline 1 bulan & 308,67 & a & 399,25 & b & 301,00 & a \\
2 bulan & 284,33 & a & 245,00 & a & 270,33 & a \\
3 bulan & & & & & & \\
\hline BNT 5\% & & & & & & \\
\hline
\end{tabular}

Keterangan: Angka-angka yang didampingi huruf besar yang sama pada kolom yang sama dan huruf kecil yang sama pada baris yang sama menunjukkan tidak berbeda nyata pada uji BNT 5\%. 
Peranan mikroorganisme dapat meningkatkan transformasi kimia selama proses dekomposisi, merombak polisakarida menjadi karbon dan air serta merangsang pela-pukan sisa-sisa tanaman menjadi artikel yang lebih kecil. Didukung dengan pemelitian Syafruddin (2013) yang menyatakan bahwa penggunaan mikroorganisme efektif (EM) merupakan salah satu teknologi yang dapat digunakan dalam usaha pengelolaan pertanian yang mampu mengurangi pengaruh negatif terhadap lingkungan. Winarso (2005) mengatakan bahwa apabila hara terpenuhi melalui kompos dan pemupukan hingga mencapai kebutuhan optimal bagi tanaman maka akan meningkatkan produksi tanaman.

\section{Bobot Segar Bunga per Hektar}

Penambahan kompos pada pertumbuhan tanaman kubis bunga menunjukkan hasil yang tinggi hingga pada hasil produksi. Perkembangan tanaman pada fase vegetatif berpengaruh pada produktifitas yang dihasilkan tanaman pada saat panen. Semakin besar diameter bunga yang dihasilkan akan mendukung bobot segar tanaman ${ }^{-1}$ semakin besar, sehingga akan berbanding lurus dengan bobot segar hektar ${ }^{-1}$ tanaman kubis bunga. Dosis EM4 20\% dengan lama pengomposan 2 bulan menunjukkan hasil yang lebih tinggi pada semua parameter pengamatan seperti terlihat pada tabel 7. Menurut penelitian Balittanah (2006), pengomposan akan meningkatkan kadar hara makro. Zat-zat hara yang terkandung dalam bahan akan diubah menjadi bentuk yang mudah diserap tanaman. Hasil penelitian Widarma (2016) yang menunjukkan bahwa hasil panen kubis bunga tertinggi terdapat pada perlakuan pemberian kompos limbah kayu dan mulsa terdapat 20 ton ha ${ }^{-1}$ menghasilkan bobot krop tanaman kubis bunga meningkat 43,15\%.

Produksi tanaman yang tinggi akan menghasilkan presentase dari pertumbuhan yang baik. Lama pengomposan menurut Nurullita (2012) ditetapkan berdasarkan penyusutan bobot sampah sampai dengan 60\% dan memperhitungkan standar fisik kompos seperti tekstur yang menyerupai tanah.. Dengan demikian ditinjau dari unsur hara yang dihasilkan lama pengomposan 2 bulan dengan dosis EM4 20\% berpotensi menghasilkan pertumbuhan dan hasil panen yang optimal.

Tabel 7. Pengaruh interaksi perlakuan dosis EM4 dan lama pengomposan terhadap bobot segar bunga hektar ${ }^{-1}$ (ton) tanaman kubis bunga

\begin{tabular}{crrrrrr}
\hline \multirow{2}{*}{ Lama Pengomposan } & $10 \%$ & $20 \%$ & $30 \%$ & \\
\cline { 2 - 7 } & 11,25 & a & 13,86 & b & 10,64 & a \\
\hline 1 bulan & 12,36 & ab & 15,97 & b & 12,03 & a \\
2 bulan & 11,17 & a & 9,79 & a & 10,81 & a \\
3 bulan & & & & & \\
\hline
\end{tabular}

BNT 5\%

2,43

Keterangan: Angka-angka yang didampingi huruf besar yang sama pada kolom yang sama dan huruf kecil yang sama pada baris yang sama menunjukkan tidak berbeda nyata pada uji BNT 5\%. 


\section{Kesimpulan}

Berdasarkan hasil penelitian dapat disimpulkan bahwa perlakuan dosis EM4 dengan lama pengomposan menunjukkan pengaruh terhadap pertumbuhan dan hasil tanaman kubis bunga. Dosis EM4 20\% dengan lama pengomposan 2 bulan memberikan hasil lebih tinggi pada semua parameter pengamatan. Kubis bunga dengan dosis EM4 20\% dengan lama pengomposan 2 bulan menghasilkan bobot segar sebesar 15,97 ton $\mathrm{ha}^{-1}$, pada dosis EM4 20\% dengan lama pengomposan 1 bulan menghasilkan bobot segar 13,86 ton ha ${ }^{-1}$, sedangkan hasil terendah pada dosis EM4 20\% dengan lama pengomposan 3 bulan menghasilkan bobot segar 9,79 ton $\mathrm{ha}^{-1}$.

\section{Daftar Pustaka}

Ambarwati, D.L. S dan Y. Kusumawati. 2006. Peran Effective Innoculant 4 dalam Meningkatkan Kualitas Kimia Kompos Ampas Tahu. Program Studi Kesehatan Masyarakat, Fakultas Ilmu Kedokteran, Universitas Muhammadiyah. Surakarta.

Hardiwinoto, S., Arianto D dan Okimori Y. 1996. Litter Production and Input of Logged Over Forest in The Tropical Rain Forest of Jambi, Sumatra dalam Khemnark et al (eds), Tropical Forestry in the 21 st century, Bangkok. 1996. Pp. $48-66$

Manuputty, M.C., A. Jacob dan J.P. Haumahu. 2012. Pengaruh Effective Inoculant Promi dan EM4 terhadap Laju Dekomposisi dan Kualitas Kompos Dari Sampah Kota Ambon. Agrologia. 1(2): 143-151
Mirwan, Mohamad dan Firra Rosariawari. Percepatan Waktu Pengomposan menggunakan Kombinasi Aktivator EM4 dan Starbio dengan Metode Bersusun. Jurnal Ilmiah Teknik Lingkungan. 5 (1) : $70-76$.

Nurullita, Ulfa dan Budiyono. 2012. Lama Waktu Pengomposan Sampah Rumah Tangga Berdasarkan Jenis Mikroorganisme local (Mol) dan Teknik Pengomposan. Seminar Hasil Penelitian. LPPM Unimus.

Pusat Pendidikan Lingkungan Hidup. 2007. Limbah Kayu. Seloliman Trawas. Mojokerto. 42 hal.

Qoida, N. 2015. Pengaruh Pemberian Bioaktivator EM4 dan Ragi Tempe Pada Limbah Cair Tahu terhadap Pertumbuhan Tanaman Tomat (Solanum bycopersicum L.) Var. Tymoti F1. Skripsi. Ilmu Pendidikan Biologi. Fakultas Ilmu Tarbiyah dan Keguruan. Universitas Islam Negeri Walisongo. Semarang.

Siswati, Dyah Nana, Herwindo, Theodorus dan Puguh, Wahyu Eko S. 2009. Kajian Penambahana Effective Microoganisms (EM4) Pada proses Dekomposisi limbah Padat Industri kertas. Buana Sains. $9(1: 63-68)$.

Sudarmin. 1999. Pemanfaaatan EM4 sebagai Biofermentasi pada Sampah Organik Rumah Tangga. Laporan Penerapan Ipteks Dikti.

Syafruddin dan Safrizal, HD. 2013. Pengaruh Konsentrasi dan Waktu Aplikasi EM4 Terhadap Pertumbuhan dan Produksi cabai (Capsicum annum L.). Jurnal Agrista. 17 (2) : $71-7$. 